\title{
MODEL COMPOUNDS DALAM MENGHITUNG AGGREGATE LOSS
}

\author{
Tohap Manurung ${ }^{1)}$ \\ ${ }^{1)}$ Program studi Matematika FMIPA Universitas Sam Ratulangi Manado, 95115 \\ Kris_ton79@yahoo.com
}

\begin{abstract}
ABSTRAK
Penelitian ini bertujuan untuk menentukan taksiran distribusi aggregate loss. Dalam hal ini, aggregate loss merupakan total kerugian dalam periode satu tahun yang dialami oleh pemegang polis yang ditanggung suatu perusahaan asuransi. Dalam menentukan taksiran fungsi peluang aggregate loss, akan dibentuk model distribusi compound. Untuk menyelesaikan distribusi compound, ada beberapa metode yang digunakan antara lain metode Panjer Recursion, Fourier Inversion, dan Fast Fourier Transform.
\end{abstract}

Kata kunci: Aggregate loss, compound distribution

\section{COMPOUNDS MODEL TO DETERMINE AGGREGATE LOSS}

\begin{abstract}
This study aims to determine the estimated aggregate loss distribution. In this case, the aggregate loss is a total loss within one year period experienced by the policyholder who paid an insurance company. In determining the estimated aggregate loss function, will be established distribution model compound. To determine the compound distribution, there are several methods used, namely, Panjer Recursion, Fourier Inversion, dan Fast Fourier Transform.
\end{abstract}

Keywords: Aggregate loss, compound distribution

\section{PENDAHULUAN}

Dalam dunia asuransi, khususnya asuransi kerugian, akan ditemukan istilah aggregate loss. Distribusi aggregate loss dalam hal ini merupakan distribusi peluang total besarnya kerugian menurut polis asuransi. Penelitian ini bertujuan untuk menentukan taksiran distribusi aggregate loss. Distribusi aggregate loss terdiri dari distribusi frekuensi dan distribusi severity, sehingga distribusi ini disebut juga distribusi compound (compound distribution). Dalam hal ini, distribusi frekuensi yang dimaksud adalah distribusi banyaknya klaim (numbers of claim) pada suatu periode tertentu, dan distribusi severity adalah distribusi besar klaim. Distribusi aggregate loss S (distribusi total klaim) merupakan model collective risk

$$
S=X_{1}+X_{2}+\ldots+X_{N} .
$$

\section{METODOLOGI PENELITIAN}

Model distribusi aggregate loss pada penelitian ini adalah model distribusi compound distribusi banyak klaim dan distribusi besar klaim. Dari model distribusi compound tersebut ditentukan fungsi kepadatan peluang. Dalam melakukan analisis selanjutnya, dapat digunakan software MATLAB. Data yang diasumsikan dalam penelitian ini adalah data banyak klaim dan besar klaim asuransi.

\section{PEMBAHASAN}

\section{Distribusi peluang diskrit}

Distribusi peluang diskrit merupakan jenis distribusi suatu peubah acak yang memiliki ruang sampel dimana elemenelemennya dapat didaftarkan. Dalam tesis ini, elemen-elemen ruang sampel yang dimaksud adalah bilangan bulat tak negatif. Distribusi peubah acak yang demikian disebut juga 
distribusi counting. Dalam bidang asuransi, salah satu peubah acak yang berdistribusi counting adalah peubah acak yang menyatakan banyaknya klaim yang diajukan oleh pemegang polis pada suatu periode tertentu. Misalkan $N$ menyatakan peubah acak banyak klaim yang didefinisikan pada kumpulan bilangan bulat tak negatif $0,1,2$, $3, \ldots$. Maka dapat dituliskan fungsi peluang $\left(p_{k}\right)$ banyak klaim

$$
p_{k}=\operatorname{Pr}(N=k), \quad k=0,1,2,3, \ldots
$$

Fungsi pembangkit peluang peubah acak diskrit $N$ dengan fungsi peluang $p_{k}$ adalah

$$
P(z)=P_{N}(z)=E\left(z^{N}\right)=\sum_{k=0}^{\infty} p_{k} z^{k}
$$

Seperti halnya fungsi pembangkit momen yang dapat membangkitkan momen, fungsi pembangkit peluang juga dapat membangkitkan momen. Secara khusus, $P^{\prime}(1)=E(N)$ dan $\quad P^{\prime \prime}(1)=E[N(N-1)]$. Fungsi pembangkit peluang dapat membangkitkan peluang, hal ini dapat ditunjukkan seperti berikut.

$$
\begin{aligned}
P^{(m)}(z) & =E\left(\frac{d^{m}}{d z^{m}} z^{N}\right) \\
& =E\left[N(N-1) \ldots(N-m+1) z^{N-m}\right] \\
& =\sum_{k=m}^{\infty} k(k-1) \ldots(k-m+1) z^{k-m} p_{k}
\end{aligned}
$$

Untuk $z=0$, diperoleh

$$
P^{(m)}(0)=m ! p_{m} \text { atau } p_{m}=\frac{P^{(m)}(0)}{m !}
$$

[Klugman dkk. (2004), halaman 73].

\section{Distribusi claim frequency}

Para aktuaris umumnya menemukan bahwa dalam banyak kasus, frekuensi klaim dapat dimodelkan meggunakan distribusi Poisson atau negative binomial. Fungsi peluang dari distribusi Poisson adalah

$$
p_{k}=\frac{e^{-\lambda} \lambda^{k}}{k !}, \quad k=0,1,2,3, \ldots
$$

Fungsi pembangkit peluang dari distribusi Poisson adalah

$$
P(z)=e^{\lambda(z-1)}, \quad \lambda>0
$$

Mean dan variansi dapat dihitung dari fungsi pembangkit peluang sebagai berikut,

$$
\begin{aligned}
& E(N)=P^{\prime}(1)=\lambda \\
& E[N(N-1)]=P^{\prime \prime}(1)=\lambda^{2} \\
& \operatorname{Var}(N) \quad=E[N(N-1)]+E(N)-[E(N)]^{2} \\
& \operatorname{Var}(N) \quad=\lambda^{2}+\lambda-\lambda^{2} \\
& \operatorname{Var}(N) \quad=\lambda
\end{aligned}
$$

Jadi untuk distribusi Poisson nilai variansi sama dengan nilai mean.

[Klugman dkk. (2004).

\section{Distribusi Claim severity}

Terdapat berbagai model peluang yang dapat digunakan untuk memodelkan distribusi claim severity, diantaranya: Pareto, lognormal, exponential inverse Gaussian, inverse Gaussian, Weibull dan Gamma yang diurutkan berdasarkan ukuran tail (mulai dari distribusi yang mempunyai heavier tail sampai yang mempunyai lighter tail)

\section{Distribusi Compound}

Suatu kelas distribusi yang lebih besar dapat dibentuk melalui proses compounding dua distribusi. Misalkan $P_{N}(z)$ adalah fungsi pembangkit peluang peubah acak primer $N$ (primary distribution) dan $P_{M}(z)$ adalah fungsi pembangkit peluang peubah acak sekunder $M$ (secondary distribution). Maka fungsi pembangkit peluang compound distribution dari kedua peubah acak tersebut dapat dituliskan sebagai

$P(z)=P_{N}\left[P_{M}(z)\right]$,

Distribusi yang terbentuk dinamakan distribusi compound. Distribusi compound dapat dibentuk dengan cara sebagai berikut.

Misalkan $N$ suatu peubah acak berdistribusi counting yang memiliki fungsi pembangkit peluang $P_{N}(z)$. Misalkan $M_{1}$, 
$M_{2}, \quad \ldots$, peubah acak yang berdistribusi identik dan saling bebas dengan fungsi pembangkit peluang $P_{M}(z)$. Dengan mengasumsikan bahwa peubah acak $M_{j}$ tidak bergantung pada $N$, fungsi pembangkit peluang dari jumlah acak $S=M_{1}+M_{2}+\ldots+$ $M_{N}$ (di mana $N=0$ mengakibatkan $S=0$ ) adalah $\quad P_{S}(z)=P_{N}\left[P_{M}(z)\right]$. Dapat ditunjukkan sebagai berikut

$$
\begin{aligned}
P_{S}(z) & =\sum_{k=0}^{\infty} \operatorname{Pr}(S=k) z^{k} \\
& =\sum_{k=0}^{\infty} \sum_{n=0}^{\infty} \operatorname{Pr}(S=k \mid N=n) \operatorname{Pr}(N=n) z^{k} \\
& =\sum_{n=0}^{\infty} \operatorname{Pr}(N=n) \sum_{k=0}^{\infty} \operatorname{Pr}\left(M_{1}+\ldots+M_{n}=k \mid N=n\right) z^{k} \\
& =\sum_{n=0}^{\infty} \operatorname{Pr}(N=n)\left[P_{M}(z)\right]^{n} \\
& =P_{N}\left[P_{M}(z)\right]
\end{aligned}
$$

Selanjutnya peluang dari $S=k$ dapat ditulis sebagai berikut

$$
\begin{aligned}
\operatorname{Pr}(S=k) & =\sum_{n=0}^{\infty} \operatorname{Pr}(S=k \mid N=n) \operatorname{Pr}(N=n) \\
& =\sum_{n=0}^{\infty} \operatorname{Pr}\left(M_{1}+\ldots+M_{N}=k \mid N=n\right) \operatorname{Pr}(N=n) \\
& =\sum_{n=0}^{\infty} \operatorname{Pr}\left(M_{1}+\ldots+M_{n}=k\right) \operatorname{Pr}(N=n)
\end{aligned}
$$

Dengan memisalkan

$$
g_{n}=\operatorname{Pr}(S=n), p_{n}=\operatorname{Pr}(N=n) \mathrm{da}
$$

n $f_{n}=\operatorname{Pr}(M=n)$

diperoleh

$$
\operatorname{Pr}(S=k)=g_{k}=\sum_{n=0}^{\infty} p_{n} f_{k}^{*_{n}}
$$

di mana $f_{k}^{* n}, k=0,1, \ldots$, adalah konvolusi lipatan- $n$ dari $f_{k}$, dengan $k=0,1, \ldots$, yaitu peluang dari jumlah $n$ buah peubah acak yang berdistribusi identik dan saling bebas dengan fungsi peluang $f_{k}$. [Klugman dkk. (2004), halaman 88-91].
Untuk setiap distribusi compound, $g_{0}=P_{N}\left(f_{0}\right)$ di mana $P_{N}(z)$ merupakan fungsi pembangkit peluang dari distribusi primary dan $f_{0}$ merupakan peluang peubah acak distribusi secondary di titik nol.

Bukti:

$$
\begin{gathered}
g_{0}=\operatorname{Pr}(S=0)=P(0) \\
g_{0}=P_{N}\left[P_{M}(0)\right] \\
g_{0}=P_{N}[f(0)]
\end{gathered}
$$

[Klugman dkk. (2004), halaman 93].

\section{Model Aggregate Loss}

Aggregate loss adalah total kerugian yang dialami oleh pemegang polis yang harus ditanggung oleh perusahaan asuransi dalam suatu periode waktu tertentu. Metode yang digunakan untuk memperoleh aggregate loss adalah mencatat masing-masing besar klaim (payments) dan menjumlahkan semua klaim tersebut. Aggregate loss dapat dinyatakan dengan suatu peubah acak $S$. Banyak klaim dalam satu periode dari suatu portofolio dapat dinyatakan dengan peubah acak $N$. Besar masing-masing klaim dapat dinyatakan dalam peubah acak $X_{1}, X_{2}, \ldots$. Dengan demikian diperoleh suatu model collective risk

$$
S=X_{1}+X_{2}+\ldots+X_{N}, \quad N=0,1,2, \ldots,
$$

di mana $S=0$ jika $N=0$.

Asumsi-asumsi yang harus diperhatikan pada aggregate loss untuk model collective risk yaitu :

1. Diberikan $N=n$, peubah acak $X_{1}, X_{2}, \ldots$, $X_{n}$ merupakan peubah acak yang berdistribusi identik dan saling bebas.

2. Diberikan $N=n$, distribusi bersama dari peubah acak $X_{1}, X_{2}, \ldots, X_{n}$ tidak bergantung pada nilai $n$.

3. Distribusi dari peubah acak $N$ tidak bergantung kepada nilai-nilai dari peubah acak $X_{1}, X_{2}, \ldots$

\section{Model Compound for Aggregate Loss}

Misalkan S menyatakan aggregate loss dengan model persamaan (11) dan memenuhi asumsi-asumsi di atas. Peubah acak $S$ memiliki fungsi distribusi: 


$$
\begin{aligned}
F_{S}(x) & =\operatorname{Pr}(S \leq x) \\
& =\sum_{n=0}^{\infty} \operatorname{Pr}(S \leq x \mid N=n) \cdot p_{n} \\
& =\sum_{n=0}^{\infty} p_{n} F_{x}^{*_{n}}(x),
\end{aligned}
$$

di mana $F_{X}(x)=\operatorname{Pr}(X \leq x)$ adalah common distribution function dari $X$ dan $p_{n}=\operatorname{Pr}(N=n) . F_{X}^{* n}$ adalah konvolusi lipatan ke- $n$ dari fungsi distribusi $X$. Konvolusi lipatan- $n$ diperoleh sebagai berikut

dan

$$
F_{X}^{* 0}(x)= \begin{cases}0, & x<0 \\ 1, & x \geq 0\end{cases}
$$

$$
\begin{gathered}
F_{X}^{* k}(x)=\int_{-\infty}^{\infty} F_{X}^{*(k-1)}(x-y) d F_{X}(y) \text { untuk } k \\
=1,2, \ldots
\end{gathered}
$$

Jika $X$ adalah peubah acak kontinu dengan fungsi kepadatan peluang terdefinisi pada bilangan tak negatif, persamaan (13) menjadi

$$
\begin{gathered}
F_{X}^{* k}(x)=\int_{0}^{x} F_{X}^{*(k-1)}(x-y) f_{X}(y) d y \text { untuk } k \\
=2,3, \ldots
\end{gathered}
$$

Untuk $k=1$ persamaan ini menghasikan $F_{X}^{* 1}(x)=F_{X}(x)$. Dengan cara menurunkan (14), diperoleh fungsi kepadatan peluangnya adalah

$$
\begin{gathered}
f_{X}^{* k}(x)=\int_{0}^{x} f_{X}^{*(k-1)}(x-y) f_{X}(y) d y \text { untuk } k \\
=2,3, \ldots
\end{gathered}
$$

Dalam kasus peubah acak diskrit dengan peluang positif pada $0,1,2, \ldots$, persamaan (13) menjadi

$$
\begin{gathered}
F_{X}^{* k}(x)=\sum_{y=0}^{x} F_{X}^{*(k-1)}(x-y) f_{X}(y) \text { untuk } x \\
=0,1, \ldots, \quad k=2,3, \ldots \quad(16)
\end{gathered}
$$

Fungsi kepadatan peluangnya adalah

$$
\begin{gathered}
f_{X}^{* k}(x)=\sum_{y=0}^{x} f_{X}^{*(k-1)}(x-y) f_{X}(y) \text { untuk } x \\
=0,1, \ldots, \quad k=2,3, \ldots \quad \text { (17) }
\end{gathered}
$$

Distribusi $S$ persamaan (12) disebut distribusi compound, dan fungsi peluang aggregate loss nya adalah

$$
f_{S}(x)=\sum_{n=0}^{\infty} p_{n} f_{X}^{* n}(x) \text {. }
$$

[Klugman dkk. (2004), halaman 140 dan 141].

Persamaan (18) adalah formula untuk menghitung besar peluang aggregate loss. Jika persamaan (18) digunakan secara langsung untuk menghitung fungsi peluang aggregate loss akan tidak efisien dan sangat rumit terutama untuk ukuran selang $k$ yang besar. Perlu digunakan metode yang lain dalam menyelesaikannya, misalnya Fast Fourier Transform.

\section{KESIMPULAN DAN SARAN}

Dalam menghitung aggregate loss distribution untuk kasus asuransi kerugian, model distribusi Compound sangatlah berperan. Dalam hal ini, distribusi compound merupakan gabungan distribusi banyak klaim ( number of claims) dan besar klaim (amount of claims). Distribusi compound tersebut dapat dianalisis selanjutnya dengan beberapa metode seperti Fast Fourier Transform(FFT).

\section{DAFTAR PUSTAKA}

Klugman, Stuart A., Panjer, Harry H., dan Willmot, Gordon E. 2004. Loss Models from Data to Decisions. Second Edition. John Wiley and Sons, New Jersey.

Sarsono, A. 2009. Analisis Data Total Klaim untuk Menentukan Risk Premium pada Asuransi Mobil. Tugas Akhir Sarjana Program Studi Matematika FMIPA Institut Teknologi Bandung. 